\title{
Optimal Design System and Control of Stand-Alone PV System Considering Iraq Region
}

\section{Ahmed M. Betti and M.A. Mustafa Hassan \\ Electrical Power Department, Southern Technical University; Basra, Iraq and Electrical Power Department, Cairo University; Giza, Egypt}

Correspondence Author: Ahmed M. Betti, Elec. Power Department, Southern Technical University; Basra, Iraq , Elec. Power Department, Cairo University, Giza, Egypt.

E-mail: ahmedsmss22@gmail.com

Received date: 15 April 2018, Accepted date: 15 June 2018, Online date: 5 July 2018

Copyright: ( 2018 Ahmed M. Betti and M.A. Mustafa Hassan. This is an open-access article distributed under the terms of the Creative Commons Attribution License, which permits unrestricted use, distribution, and reproduction in any medium, provided the original author and source are credited.

\begin{abstract}
This paper provides a study of the design for stand-alone photovoltaic (PV) system to provide electricity for the purposes required for family in Iraq the system is created on the data of solar radiation site studied as well as electric load data for the houses in the same site. proposed Maximum Power Point Tracking (MPPT) control loop and using the best techniques Perturb and Observe (P\&O) Algorithm extracting maximum power from PV module under different solar irradiation, To control the process of charging battery and discharging the battery in different cases use PID control to stay the input dc voltage constant at steady state and tuning parameters was done through the use Particle Swarm Optimization (PSO). The proposed method is applied to generation $3.5 \mathrm{~kW}, 210 \mathrm{~V}, 50 \mathrm{~Hz}$, three -phase standalone PV system. A software simulation model is developed in Matlab/Simulink.
\end{abstract}

Key words: Photovoltaic Stand-Alone Power System; System Sizing; PID control; MPPT.

\section{INTRODUCTION}

Currently, the world suffers from numerous environmental troubles due to the harmful gases emitted from burning fossil fuels. These gases destruct the ozone layer and cause a negative climatic change (Omar Rgab, D.L. Yu and J.B. Gomm, 2010). Therefore, renewable energy, such as photovoltaic arrays, fuel cell, small-scale hydropower plants, wind turbines and biomass had become the best choice in different distributed generation applications (Fathabadi, H., 2017; Meng Hui Wang, 2016). Most of the countries today move to the largest source of renewable energy which is solar radiation (Darabian, A., 2013).

The energy of solar radiation is converted to electrical energy with no moving portions included in the photovoltaic (PV) power system generators. Today PV energies are developing at a great step than the other economy through the world.

Because PV energy production is clean, freely infinitely available and of high reliability, it is a very attractive power source for many applications, especially in rural and remote areas in Media- terrane an countries where they have a large quantity of solar radiation around the year. Those solar PV systems are able to produce sufficient power to meet an electrical demand. The PV systems are renewable energy classified into stand-alone, grid-connected generators and network connected solar power plants (Nisha Ravi, 2015; Muhammad H. Rashid, Ph.D., 2016). In latest years there is a purpose to combine renewable resources so that each one gives a certain advantage "(e.g., photovoltaic, wind turbines, micro-turbines, biomass, and fuel-cells , etc.)" (Dolara, A., 2009). This papers concerned by stand-alone PV generator with batteries. Those solar PV systems are able to produce sufficient power to meet an electrical demand. Iraq is blessed with an abundance of solar energy. The average peak sun hours (PSH) for Iraq of five are shown in Fig.1. (Austin, Curtis, 2005). the colors represent the average hours of PSH per day.

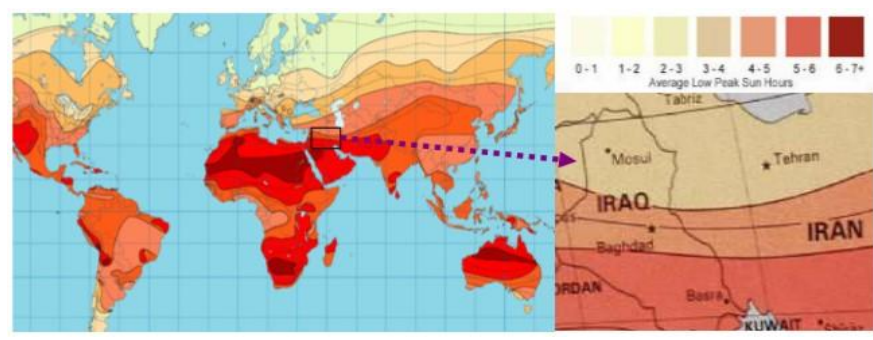

Fig. 1: Iraq Solar Power.

The possible amount of generating power and the scope of thermal applications using solar energy is huge. Most parts of Iraq get 300 days of sunshine per year. This makes the country a very promising place for solar energy utilization. The annual daily average solar irradiance (average insulation intensity on a horizontal surface) ranges between $4-7 \mathrm{kWh} / \mathrm{m} 2$, which is one of the highest in the world shown in Table 1 (Tsai, H.L., 2008).

PV Modeling:

PV cells are connected together to form larger units called modules which can be connected to form even larger units called arrays These arrays are connected in parallels and series to meet the required electricity demand as Fig. 2. (Villalva, G., 2009; Chenni, R., 2011). 
Table 1: System Energy Production Estimate.

\begin{tabular}{|l|r|r|r|r|}
\hline \multicolumn{5}{|l|}{$\begin{array}{l}\text { Fixed system: inclination=31 deg., } \\
\text { orientation=0 deg. (Optimum at given } \\
\text { orientation) }\end{array}$} \\
\hline Month & \multicolumn{1}{|l|}{ Ed } & Em & Hd & Hm \\
\hline Jan & 11.50 & 358 & 4.58 & 142 \\
\hline Feb & 13.60 & 382 & 5.54 & 155 \\
\hline Mar & 15.30 & 474 & 6.40 & 199 \\
\hline Apr & 14.70 & 441 & 6.40 & 192 \\
\hline May & 15.50 & 480 & 6.91 & 214 \\
\hline Jun & 16.00 & 479 & 7.30 & 219 \\
\hline Jul & 15.80 & 491 & 7.32 & 227 \\
\hline Aug & 16.10 & 499 & 7.45 & 231 \\
\hline Sep & 16.40 & 491 & 7.41 & 222 \\
\hline Oct & 13.90 & 431 & 6.04 & 187 \\
\hline Nov & 12.70 & 381 & 5.18 & 156 \\
\hline Dec & 11.60 & 360 & 4.61 & 143 \\
\hline Year & 14.40 & 439 & 6.26 & 191 \\
\hline Total for & & 5270 & & 2290 \\
year & & & & \\
\hline
\end{tabular}

\section{Where:}

E d: Average daily electricity production from the given system $(\mathrm{kWh})$

Em: Average monthly electricity production from the given system $(\mathrm{kWh})$

$\mathrm{Hd}$ Average daily sum of global irradiation per square meter received by the modules of the given system $(\mathrm{kWh} / \mathrm{m} 2)$

Hm: Average sum of global irradiation per square meter received by the modules of the given system $(\mathrm{kWh} / \mathrm{m} 2)$

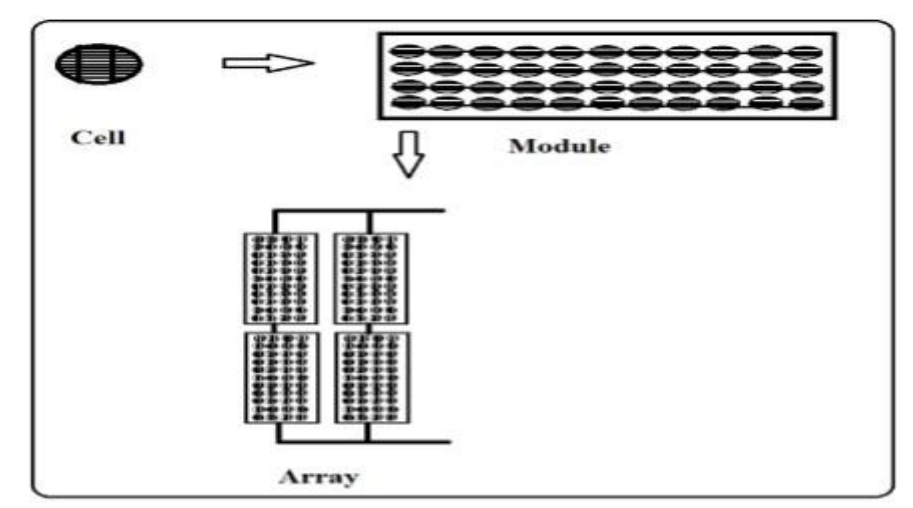

Fig. 2: PV Cells, Modules and Array.

Photovoltaic effect can be directly converting the electromagnetic radiation of solar energy into electricity. Being exposed to the daylight, photons with energy bigger than the band-gap energy of the PV cells makes certain electron-hole pairs comparative to the incident light. The equivalent circuit of a PV cell is shown below Fig. 3.

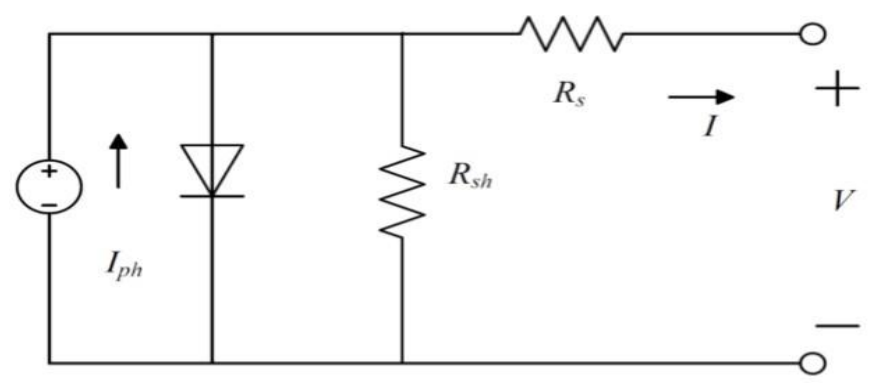

Fig. 3: PV Cell Modeled As Diode Circuit.

\section{Household PV System:}

The main configuration of the stand-alone photovoltaic (PV) system, as shown in the Fig .4. Represents the main parts of the system .The function of the PV array are to convert the sunlight directly into DC electrical power. The inverter is used to convert the DC electrical power into AC power; to match the requirements of the common household AC appliances. The excessive part of DC power is stored in the battery to be used when there is no sunshine. The controller monitors the electrical input from the solar panels and controls the amount going directly into the inverter and the amount for charging and discharging of the battery bank. 
Citation: Ahmed M. Betti and M.A. Mustafa Hassan, Optimal Design System and Control of Stand-Alone PV System Considering Iraq Region. Australian Journal of Basic and Applied Sciences, 12(7): 98-105.

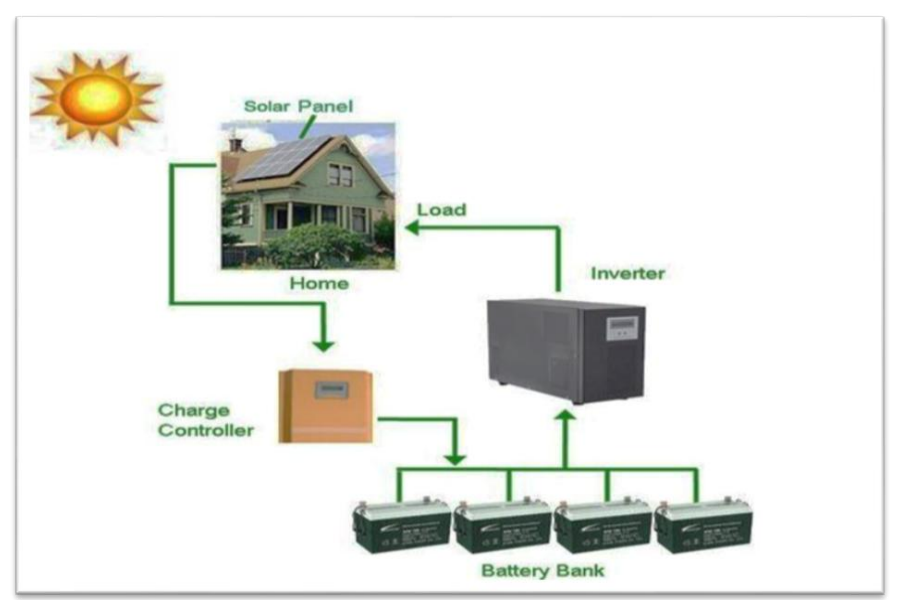

Fig. 4: Schematic of Stand-alone PV System.

Prepare Site Meteorological Data:

To predict the performance of a PV system in a location, it is necessary to collect the meteorological or environ- mental data for the site location under consideration. The monthly average monthly solar radiation data incident on a horizontal surface at the considered site is shown in Fig. 5. It is clear from Figure 2 that solar energy incident in the considered site is very high especially during the summer months, where it exceeds $7 \mathrm{kWh} / \mathrm{m} 2 / \mathrm{day}$ on horizontal. It is clear from Table 1 that even in winter, Iraq enjoys more than twenty days of sunshine per month (Lynn, Paul A., 2011).

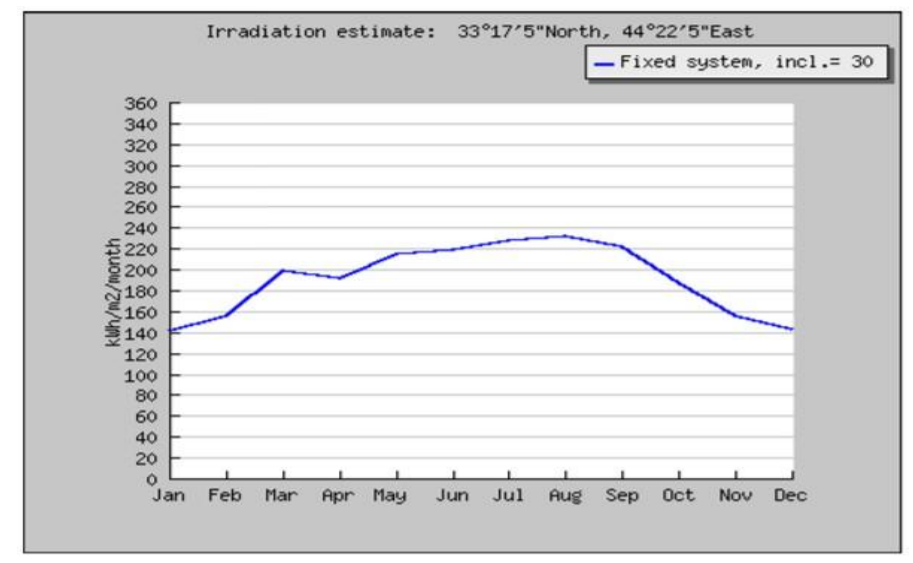

Fig. 5: Estimated Solar Irradiation for the Same Location.

Iraq is Located: $33^{\circ} 18^{\prime} 46^{\prime \prime}$ North, $44^{\circ} 21^{\prime} 41^{\prime \prime}$ East longitude. Tilt angle is defined as the angle of inclination of a module measured from the horizontal. Since the considered site is located at $33^{\circ} 18^{\prime} 46^{\prime \prime}$ North, $44^{\circ} 21^{\prime} 41$

East longitude, the optimal angle for solar panels is to be $31^{\circ}$ degree facing south (Bataineh, Khaled and Doraid Dalalah, 2012). According to Fig.6. Shows monthly solar radiation levels in the same form as table 1 . Three representative values of tilt are illustrated: $33^{\circ}, 31^{\circ} ; 48^{\circ}$ (the latitude angle); and $63^{\circ}$. As expected, $31^{\circ}$ does best over the summer months when the Sun is high in the sky (an even smaller tilt would give better results at midsummer, but at the expense of other times of year.

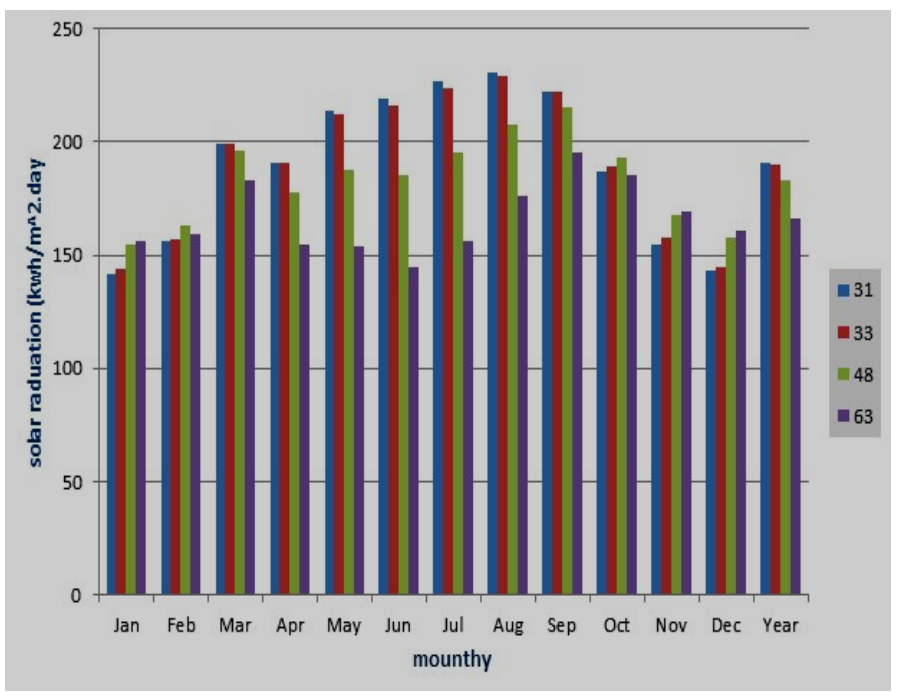

Fig. 6: Monthly Average Daily Global Irradiation on a Horizontal Surface and on Angles Four at the Considered Site of Array Title are Illustrated. 
Citation: Ahmed M. Betti and M.A. Mustafa Hassan, Optimal Design System and Control of Stand-Alone PV System Considering Iraq Region. Australian Journal of Basic and Applied Sciences, 12(7): 98-105.

\section{Electrical Demand:}

The electrical loads include lighting, medium size refrigerator, one microwave oven and other ordinary household electrical appliances, e.g. TV sets, , etc. The daily electrical demand in a typical day for each device is shown in Table 2. It is assumed that this load is constant around the year. The corresponding load profile for a typical day is indicated in Fig. 7. The average daily load demand EL can be calculated from Table 2 to be $14230 \mathrm{Wh} / \mathrm{day}$

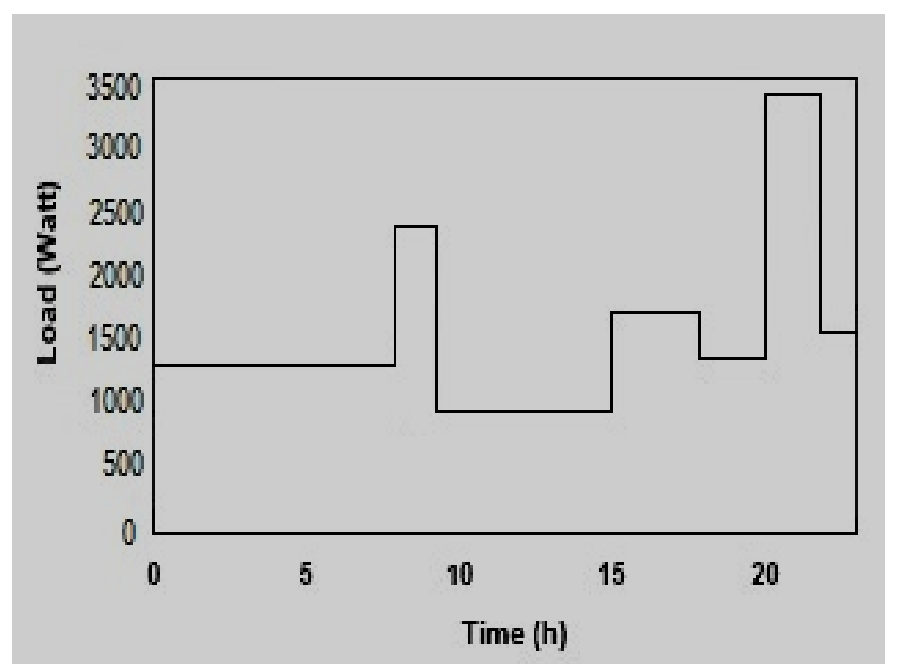

Fig. 7: The Load Profile of the Household.

Table 2: The Household Load Data.

\begin{tabular}{|c|c|c|c|c|}
\hline Application & $\begin{array}{c}\text { Power } \\
(\mathbf{w})\end{array}$ & No & $\begin{array}{c}\text { Average } \\
\text { Hrs/day }\end{array}$ & $\begin{array}{c}\text { Average } \\
\text { Wh/day }\end{array}$ \\
\hline Light & 15 & 5 & 6 & 450 \\
\hline $\begin{array}{c}\text { Microwave } \\
\text { Oven }\end{array}$ & 700 & 1 & 1 & 700 \\
\hline TV & 120 & 1 & 8 & 960 \\
\hline Computer & 60 & 1 & 4 & 240 \\
\hline Refrigerator & 165 & 1 & $\begin{array}{c}\text { On-off } \\
24\end{array}$ & 1980 \\
\hline $\begin{array}{c}\text { Air } \\
\text { conditioner }\end{array}$ & 1200 & 1 & 6 & 7200 \\
\hline FOOD mixer & 400 & 1 & 1 & 400 \\
\hline $\begin{array}{c}\text { Washing } \\
\text { Machine }\end{array}$ & 800 & 1 & 2 & 1600 \\
\hline Fan roofx & 40 & 3 & 10 & 1200 \\
\hline & $3500 \mathrm{~W}$ & & & $14730 \mathrm{WH}$ \\
/day
\end{tabular}

The output of a PV array is related to the light intensity falling on the PV array, ambient temperature, cell temperature, load status and characteristics of PV mod- ules. Since the PV array considered in this study is tilted $31^{\circ}$ facing south

Sizing of PV Modules:

The numbers of PV modules are determined by the following expressions

$$
\text { Number of modules }=\frac{\text { PV peak powet }}{\text { Peak power of a module }}
$$

Where PV peak power is calculated by

\section{$P V$ peakpower $=$ PVarea $* P S I * \eta p v$}

Where PSI is the maximum radiation intensity taken to be $1000 \mathrm{~W} / \mathrm{m} 2$, and the peak power of the selected module is $250 \mathrm{~W}$ (Shaw, Priyabrata, et al., 2016). The numbers of modules in parallel NMP and series are calculated by:

$$
N M P=\frac{I t o t}{I m * D f}, N M s=\frac{V s}{V m}, \text { Itot }=\frac{A h T O T}{N s}
$$


Citation: Ahmed M. Betti and M.A. Mustafa Hassan, Optimal Design System and Control of Stand-Alone PV System Considering Iraq Region. Australian Journal of Basic and Applied Sciences, 12(7): 98-105.

$\begin{array}{ll}\text { Itot : } & \text { The Total PV Array Current, } \\ \text { El: } & \text { Total System Load, } \\ \text { Vs.: } & \text { System Nominal Voltage, } \\ \text { Nms: } & \text { Number of Module in Series, } \\ \text { Nmp: } & \text { Number of Module in Parallel }\end{array}$

NS is calculated from Table 1, to be 6 hours and the system nominal voltage is taken to be 36 volt. The losses and safety factor is assumed to be 1.2 . The total number of modules NM tot is $\mathrm{Nmtot}=\mathrm{Nmp} * \mathrm{Nms}$

\section{System Description:}

These systems are composed of a single array of photovoltaic panels, implemented in series and/or parallel connection depending on the power of the system. While using Boost converter DC/DC with MPPT for PV array to extract the maximum available power from them. The battery which is of Lead-Acid type is used to store the energy (Elbaset, Adel A. and M.S. Hassan, 2017), to regulate the DC-Bus voltage through a reversible current buck /boost converter DC/DC and to supply the load in the stand-alone case when low solar radiation conditions (Mutoh, N., 2006). The energy produced for PV source is transferred from the DC-Bus to the house load through a DC/AC inverter controlled and filtered by an LC filter, Based on the data acquisition (Temperature, Irradiance, DC-Bus voltage...etc.). The proposed system using in this paper in Fig. 8.

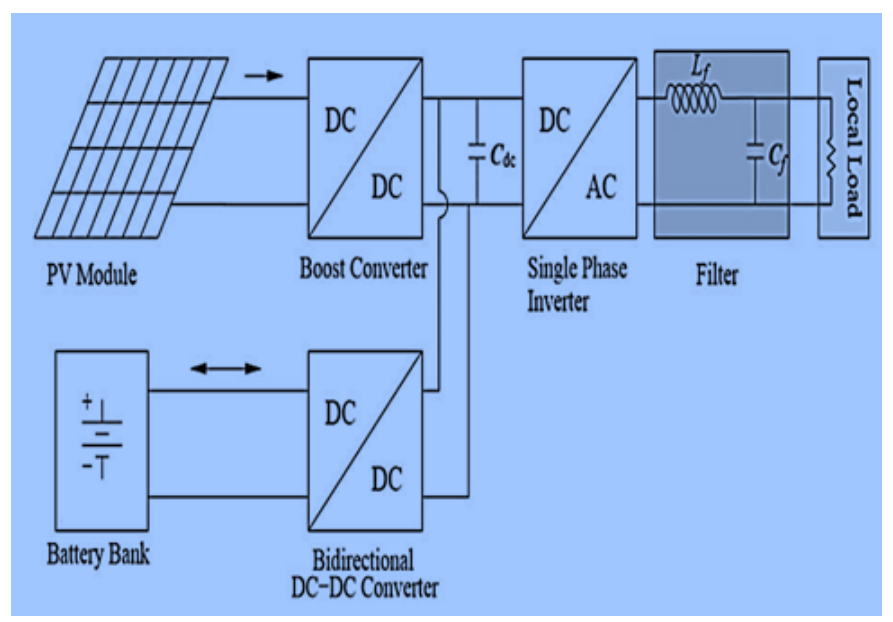

Fig. 8: Stand-alone PV Systems.

\section{MPPT Algorithms:}

Maximum power point trackers (MPPTs) play a main role in photovoltaic (PV) power systems because they maximize the power output from a PV system for a given set of conditions, and therefore maximize the array efficiency. Thus, an MPPT (Esram, T., P.L. Chapman, 2007) can minimize the overall system cost. There are many MPPT methods available the most widely-used techniques are Perturb and Observe. They also vary in complexity, sensor requirement, speed of convergence, cost, range of operation, popularity, ability to detect multiple local maxima and their applications (S.S.A.D.S.N., 2008). Specifically the Power Point Tracker is a high frequency DC to DC converter. They take the DC input from the solar panels; change it to high frequency AC,

\section{A. Perturb and Observe Algorithm:}

Operate by periodically perturbing (i.e. incrementing or decrementing) the array terminal voltage or current and comparing the PV output power with that of the previous perturbation cycle. If the PV array operating voltage changes and power increases, the control system moves the PV array operating point in that direction; otherwise the operating point is moved in the opposite direction. In the next perturbation cycle the algorithm continues in the same way. The flow chart of the Perturb and Observe algorithm shown in Fig. 9.

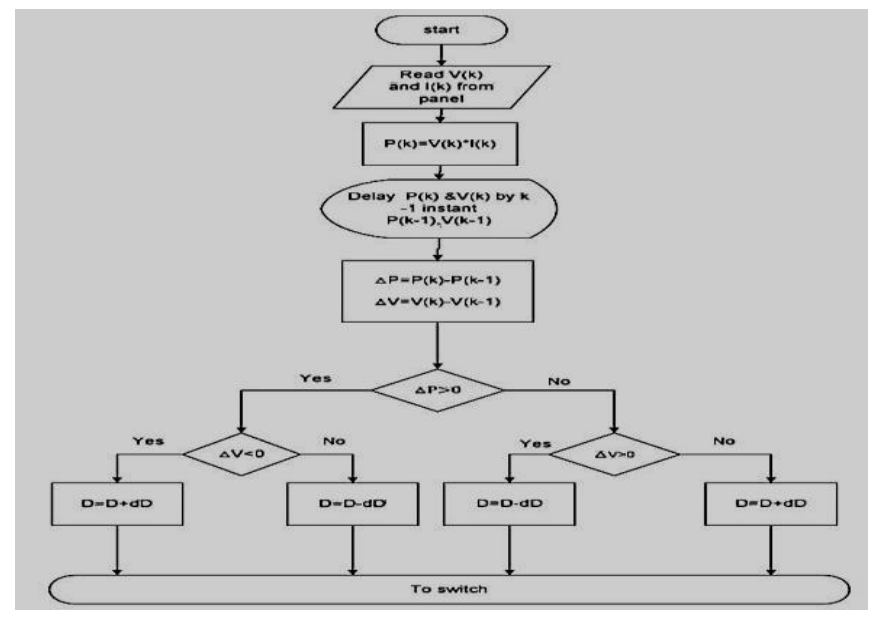

Fig. 9: Flow Chart of Perturb and Observe (P\&O) Methods.

\section{Tuning of PID Parameters:}

The tuning parameters of the FOPID are now more interested, use Particle swarm optimization (PSO). PSO simulates the same behaviour of bird flocking when a birds group flying in the sky in search of food. The food is located in a specific place and whiles the birds searching for food, each bird estimates a position of food and the bird which has the least distance from the food position will be the leader of the rest of the group's algorithm The PSO procedures flow chart is mentioned in Fig. 10.as given in (Shahin, M.E.A., 2014). 
Citation: Ahmed M. Betti and M.A. Mustafa Hassan, Optimal Design System and Control of Stand-Alone PV System Considering Iraq Region. Australian Journal of Basic and Applied Sciences, 12(7): 98-105.

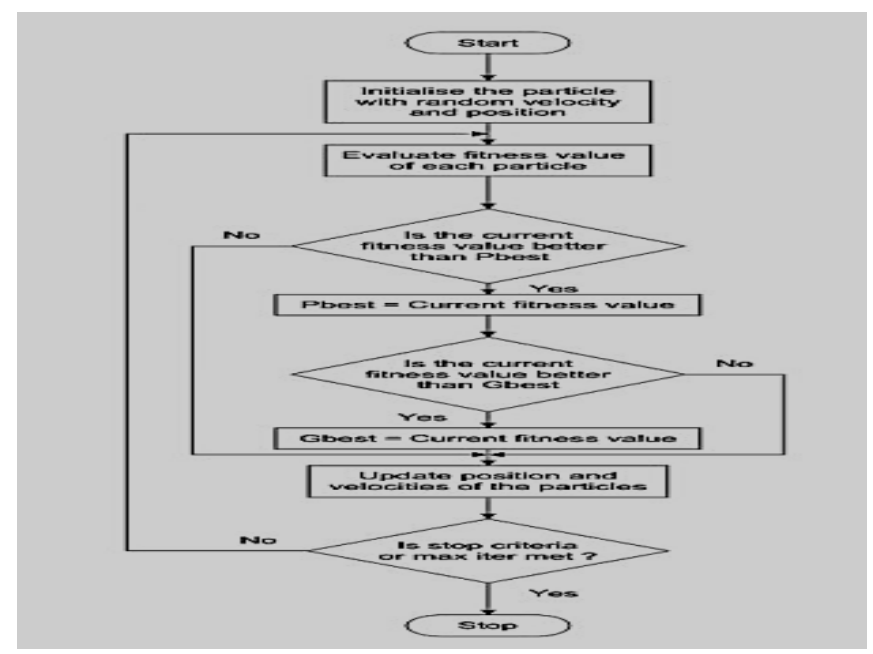

Fig. 10: Flow Chart of Simple PSO Process.

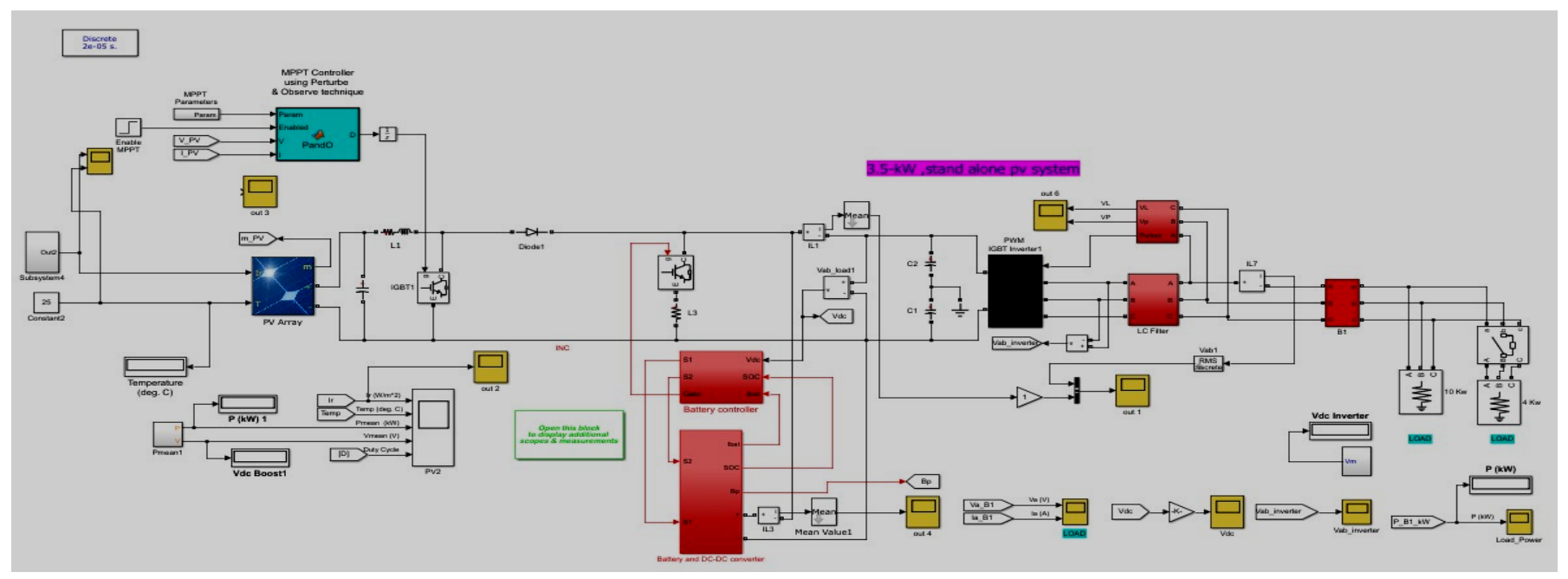

Fig. 11: The Proposed Stand-alone PV System.

RESULTS AND DISCUSSION

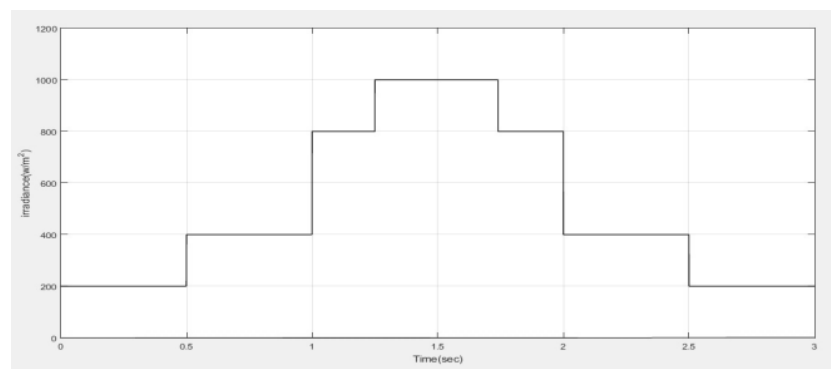

Fig. 12: Irradiance Step Change.

In Fig 13, PV output ac power in response to the change in irradiance with maximum power point tracking using Perturb and Observe Algorithm.

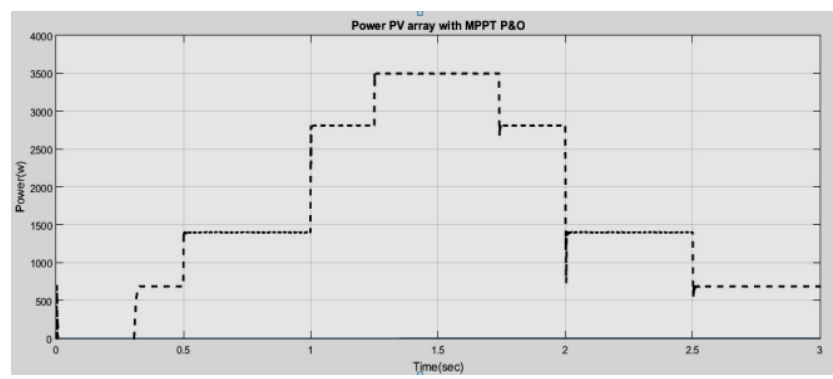

Fig. 13: Power PV Array. 
Citation: Ahmed M. Betti and M.A. Mustafa Hassan, Optimal Design System and Control of Stand-Alone PV System Considering Iraq Region. Australian Journal of Basic and Applied Sciences, 12(7): 98-105.

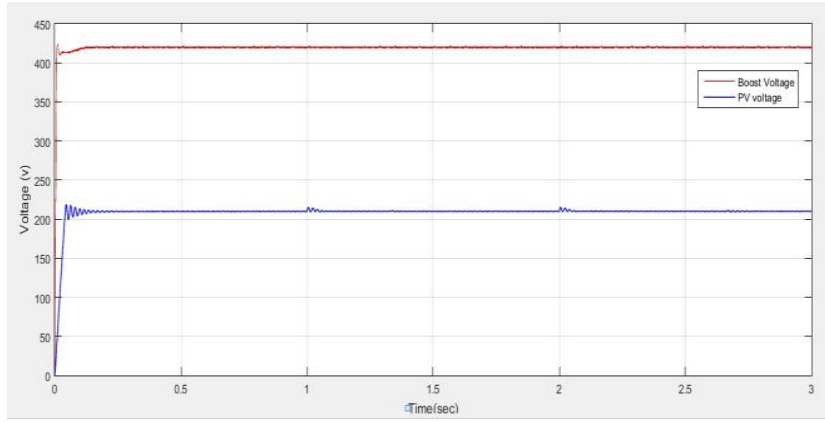

Fig. 14: Output Voltages of PV and Boost Converter.

For this load variation the steady state output voltage is shown Fig. 15, which indicates that under load variation the output voltage is remains unchanged and stable. This proves the effectiveness of inverter current control technique which is responsible for maintaining $210 \mathrm{~V}$ of constant voltage across the load.

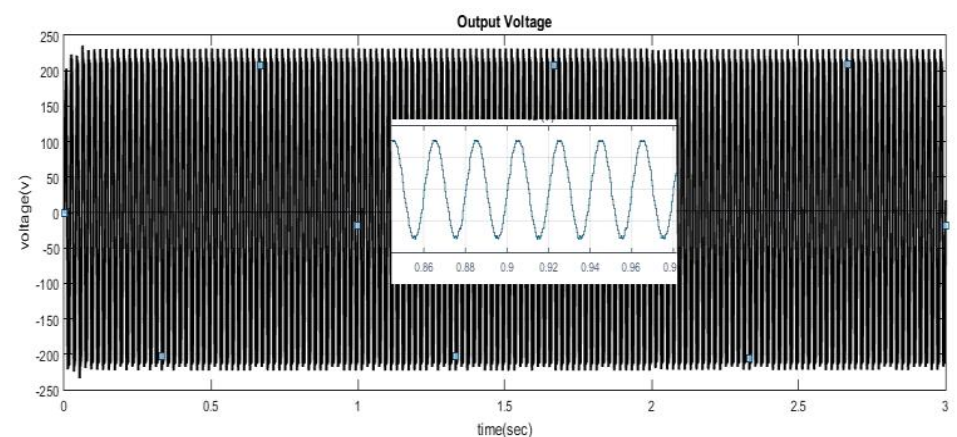

Fig. 15: Output Voltage (VO).

The output load current wave form is shown in Fig. 16 From the output current result it is clear about the load variation, as the load current changing after some specified time.

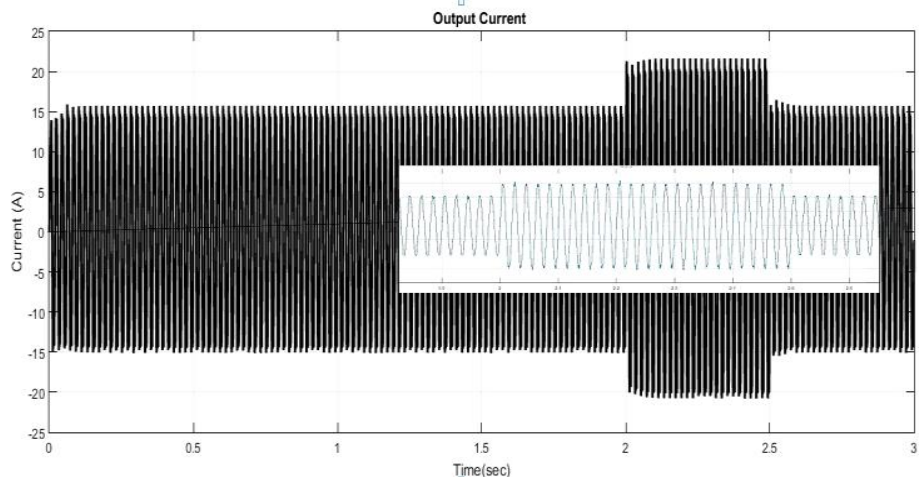

Fig. 16: Load Current (I0).

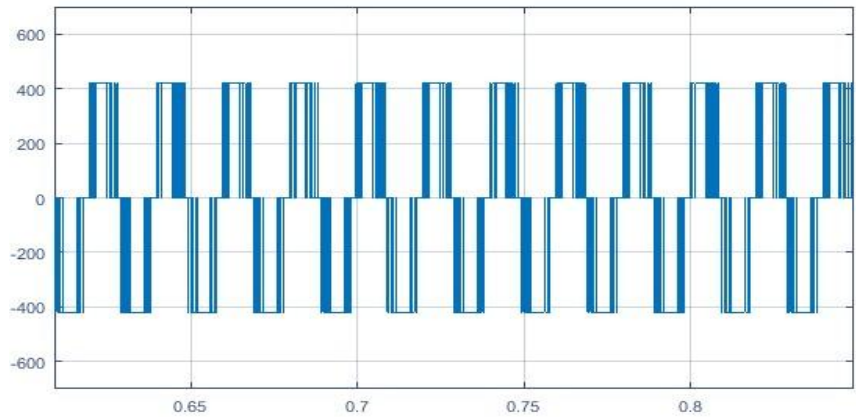

Fig. 17: Inverter Voltage.

\section{Conclusion:}

An electrification study for a single residential house in a remote isolated site of Iraq is carried out using a stand-alone PV system. According to local hourly measured meteorological data, load demand, created the optimum configuration which meets the load demand Results of research indicates using the optimal specification for electrifying isolated areas is appropriate for long investments, Overcoming the problem of load variations and irradiance fluctuation which makes the output DC voltage to change, Optimized PID used of a storage system, controller based on algorithms (PSO) are used to control the DC output voltage of the boost converter 
Citation: Ahmed M. Betti and M.A. Mustafa Hassan, Optimal Design System and Control of Stand-Alone PV System Considering Iraq Region. Australian Journal of Basic and Applied Sciences, 12(7): 98-105.

\section{ACKNOWLEDGMENT}

The authors express sincere thanks for Eng. Mohammad Essie at Institute of Aviation Engineering \& Technology at Cairo In providing the full knowledge, Also so thanks to Dr. M.A. Ebrahim.

\section{REFERENCES}

Austin, Curtis, Jeffery Phillips and Ralph Borja, 2005. "Operation Solar Eagle: a study examining photovoltaic (PV) solar power as an alternative for the rebuilding of the Iraqi electrical power generation infrastructure.".http://re.jrc.ec.europa.eu/pvgis/index.htm.

Bataineh, Khaled and Doraid Dalalah, 2012. "Optimal configuration for design of stand-alone PV system." Smart Grid and Renewable Energy, 32 : 139-147.

Chenni, R., E. Matagne and M. Khennane, 2011. "Study of Solar Radiation in View of Photovoltaic Systems Optimiza- tion," Smart Grid and Renewable Energy, 2(4): 367-374. doi:10.4236/sgre.2011.24042.

Darabian, A., R. Jalilv and M. Noroozian, 2013. 'Modeling And Control of Multi Level Inverter For Three-Phase Grid-Connected Photovoltaic Sources', International Journalon" Technical and Physical Problems of Engineering”, 5(15): 35-43.

Dolara, A., R. Faranda, S. Leva, 2009. 'Energy Comparison of Seven MPPT Techniques for PV Systems', J. Electromagnetic Analysis \& Applications, 3: $152-162$.

Esram, T., P.L. Chapman, 2007. "Comparison of Photovoltaic Array Maximum Power Point Tracking Techniques," Energy Conversion, IEEE Transactions on, 22(2): 439-449, 10.1109/TEC.2006.874230.

Elbaset, Adel A. and M.S. Hassan, 2017. Design and Power Quality Improvement of Photovoltaic Power System. Springer.

Fathabadi, H., 2017. "Novel standalone hybrid solar/wind/fuel cell power generation system for remote areas". Solar Energy, $146: 30-43$.

Lynn, Paul A., 2011. Electricity from sunlight: an introduction to photovoltaics. John Wiley \& Sons.

Meng Hui Wang, Mei-Ling Huang, Wei-Jhe Jiang, Kang-Jian Liou, 2016. "Maximum power point tracking control method for proton exchange membrane fuel cell". IET Renewable Power Generation, 10(7): 908-915.

Muhammad H. Rashid, Ph.D., 2016. Electric Renewable Energy Systems, Florida: Joe Hayton.

Mutoh, N., M. Ohno, T. Inoue, 2006. "A Method for MPPT Control While Searching for Parameters Corresponding to Weather Conditions for PV Generation Systems," Industrial Electronics, IEEE Transactions on, 53(4): 1055-1065, doi: 10.1109/TIE.2006.878328.

Nisha Ravi, Monisha Ravi, 2015. 'A study on Maximum Power Point Tracking techniques for Photovoltaic systems', International Journal of Engineering and Technical Research (IJETR), 3(1): 189-196.

Omar Rgab, D.L. Yu and J.B. Gomm, 2010. "Polymer electrolyte membrane fuel cell control with feed-forward and feedback strategy". International Journal of Engineering, Science and Technology, 2(10): 56-66.

Shaw, Priyabrata, et al., 2016. "Modeling and control of a battery connected standalone photovoltaic system." Power Electronics, Intelligent Control and Energy Systems (ICPEICES), IEEE International Conference on. IEEE.

S.S.A.D.S.N., 2008. Introduction to Genetic Algorithms, , Berlin: Springer-Verlag.

Shahin, M.E.A., 2014. "Voltage Swell Mitigation Using Flexible AC Transmission Systems Based on Evolutionary Computing Methods." International Journal of System Dynamics Applications (IJSDA), 3(3): 73-95.

Tsai, H.L., Ci-So Tu and Yi-J. Su, 2008. "Development of Generalized Photovoltaic Model Using MATLAB/SIMULINK," in World Congresson Engineering and Computer Science (WCECS), 22-24 Oe!. pp: 1-6.

Villalva, G., J.R. Gazoli and E.R. Filho, 2009. "Comprehensive approach to modeling and simulation of photovoltaic arrays," IEEE Trans. Power Electron., 24(5): I198-1208. 